7. Kostenko V. H., Bieliaieva O. M., Solohor I. M. Is the language of informed consent templates for dental treatment patient-friendly? 11th ECLSS Conferences on Language and Social Sciences. University of Gjakova «Fehmi Agani», Gjakova, Kosovo, February 02 - 03, 2021. P. 77-78.

8. Malá M. The development of sentence complexity in academic prose written in English (Psychology 1907-2005). PASE Papers. 2009. University Wroclaw. P. 79-88.

9. Mala M. Syntactic functions of finite and non-finite clauses in Academic English. Discourse and Interaction. V. 3 №1, 2010. Masaryk University, Brno. P.73 - 85. URL: https:journals.muni.cz/discourse-andinteraction/article/view/6949/8316
10. Consent
Form

\section{Sources:}

URL: https://www.padental.org/Images/OnlineDocs/ResourcesPrograms/

Practice\%20 Management/ConsentFormEndodontic.pdf.

11. Informed Consent Endodontic (Root Canal) Treatment. URL: http://absolutdent.com/wp-content/themes/biznizz/images/pdf/Informed $\% 20$ Consent $\% 20$ Endodontic\%20(Root\%20Canal)\%20Treatment.pdf
12. Informed consent
for
tooth
extraction.

URL: https://www.smilecliniq.com/wp-content/uploads/2018/12/14.-XLAConsent.pdf

13. Restorative treatment consent form. URL: https:// www.fatemifamilydentistry.com/docs/Restorative\%20 consent.pdf.

DOI https://doi.org/10.30525/978-9934-26-110-7-33

\title{
ФОРМУВАННЯ СТЕРЕОТИПУ НАЦІОНАЛЬНОЇ ІДЕНТИЧНОСТІ У АМЕРИКАНСЬКІЙ ПРЕСІ 18-ГО СТОЛІТТЯ
}

\author{
Любимова С. А. \\ кандидат філологічних наук, доцент, \\ докторант \\ Київський наиіональний лінгвістичний університет \\ м. Київ, Украӥна
}

У лінгвокогнітивному аспекті стереотип національної ідентичності $\epsilon$ вербалізованим соціальним конструктом, що формується у певному лінгвокультурному середовищі $\mathrm{i}$ репрезентує позитивний груповий 
образ. Створення негативного образу «чужого» увиразнює позитивно оцінені ознаки групи, з якою ототожнює себе індивід.

Усвідомлення національної самобутності в американському суспільстві відбувалось у колоніальний період під впливом газет, які створювали негативний образ Британії, що втілював карикатурний товстун у фраку, галіфе та жилеті з державним прапором Великобританії, ім'я якого John Bull визначає велику та галасливу людину. У сатиричному есе The History of Jon Bull's Children (1776) процвітаюча за рахунок експлуатації американських колоній Британія представлена у образі деспотичного батька - Джона Була, який кинув напризволяще своїх дітей: ...they landed on the western shore, and there nursed by a wild bear, under the green wood tree [2]. Виховані диким ведмедем, який символізує силу, непохитність та волю до перемоги американського народу, діти стали надзвичайно успішними, але все зароблене у них відбирав жадібний батько: ...they all flourished exceedingly and laid out every penny they earned for their father [2]. Заявляючи про жорстокість та недоцільність поводження Джона Була 3 дітьми (...it is both cruel and impolitic to pinch children while they cry, and then pinched them for crying), автор спонукає зробити висновок про подальшу долю дітей, які воліли свободи та самостійності.

Антагоністом Джона Була у газетній репрезентації стає простий та незграбний селюк Янкі Йолоп (Yankee Doodle), про якого йдеться мова у однойменній жартівливій пісні [1, с. 31]. Походження слова Yankee пов'язують 3 найменуванням індійського племені Yankoos, що означало «непереможний» [3]. Перші поселенці отримали цю назву від підкореного племені індіанців, яке за традицією віддавало своє ім'я переможцям: The remains of this nation (agreeable to the Indian custom) transferred their name to the conquerors [3]. Подальша доля імені убачалась у всесвітній відомості щасливого народу, якого прозвали Yankee: A name which we hope will soon be equal to that of a Roman [3].

$\mathrm{y}$ післяреволюційний період американські газети поширюють жартівливий образ грубого, але дотепного та вигадливого селюка Брата Джонатана (Brother Jonathan), який завжди отримує перемогу над Джоном Булом. Слово Brother указує на рівноправність масонського звернення «брате», а Jonathan відзначає типовість людини, чиє ім'я було розповсюдженим у Новій Англії у 17-18 століттях. Газети та альманахи представляють Брата Джонатана селюком, що народився і живе у Новій Англії, якого шанують односельці [1, с. 21-22]. На малюнках його зображують як чоловіка низького соціального статусу, одягненого у довгий сюртук, строкаті брюки та циліндр. Він самовпевнений та 
нахабний, але спритний, практичний та розважливий індивідуаліст, який може вибратись зі складних ситуацій та отримати вигоду. Ці властивості образу сприймаються в американській лінгвокультурі як типові характеристики національного характеру.

Отже, стереотипами національної самоідентифікації, що поширюються в американських газетах 18-го століття, стають образи простакуватих, але дотепних селюків, позначення яких Yankee Doodle та Brother Jonathan, з'являються у результаті епонімізації, що $є$ процесом асоціювання власного імені з набором характерних ознак стереотипу.

\title{
Література:
}

1. Morgan, W. (1988). An American Icon: Brother Jonathan and American Identity. Newark: University of Delaware Press.

2. Maryland Gazette (1766). The History of John Bull's Children. Thursday, August 14, 1766.https://www.newspapers.com/image/41039521

3. Hartford Courant (1775). Connecticut, Monday, June 12, 1775. https://www.newspapers.com/image/233770374/

DOI https://doi.org/10.30525/978-9934-26-110-7-34

\section{ВЕРБАЛЬНІ ТА НЕВЕРБАЛЬНІ ЗАСОБИ АКТУАЛІЗАЦІЇ ПРОКСЕМІЧНИХ ОБМЕЖЕНЬ В ПЕРІОД ПАНДЕМІЇ COVID-19}

\author{
Макарук Л. Л. \\ доктор філологічних наук, \\ дочент кафедри прикладної лінгвістики, \\ декан факультету іноземної філології \\ Волинський національний університет імені Лесі Украӥнки \\ м. Луиььк, Украӥна
}

Представники лінгвістичних шкіл у фокусі наукових пошуків яких постає усне мовлення, здебільшого зосереджують увагу на аналізі супровідних характеристик комунікації: темпу, тембру, дотиків, поглядів, запахів, жестів, міміки обличчя тощо, розглядаючи їх у межах просодики, паралінгвістики, кінесики, окулесики, аускультації, гаптики, гастики, ольфакції, проксеміки, хронеміки і системології. Вони отримали 